\title{
Interleukin-15 potentiates human natural killer cells to resist tumor-induced suppression through mTOR-regulated metabolic control
}

Andreas Lundqvist*, Yumeng Mao, Xiaonan Zhang, Erik Wennerberg, Vincent Van Hoef, Ola Larsson, Stig Linder, Rolf Kiessling

From 30th Annual Meeting and Associated Programs of the Society for Immunotherapy of Cancer (SITC 2015)

National Harbor, MD, USA. 4-8 November 2015

In cancer patients, anti-tumor functions of NK cells are severely impaired by a variety of immunosuppressive mechanisms. Interleukin (IL)-2 and -15 are two essential cytokines regulating the development and function of human natural killer (NK) cells. Here, we compared the role of IL-2 and IL-15 to render resistance of human NK cells to tumor-induced suppression. We found that early-passage melanoma tumor cells strongly inhibited functions of IL-2 activated NK cells through production of prostaglandin E2 (PGE2). Under the same condition, IL-15 activated NK cells could significantly retain the ability to proliferate in vitro durability, in comparison to IL-2-expanded cells. Altogether, our study uncovers distinct properties between IL- 2 and IL-15 on primary human NK cells under tumor-induced suppression. It provides evidence that implementation of IL-15 may greatly improve the clinical efficacy of adoptive NK cell therapy for the treatment of human cancers.

Submit your next manuscript to BioMed Central and take full advantage of:

- Convenient online submission

- Thorough peer review

- No space constraints or color figure charges

- Immediate publication on acceptance

- Inclusion in PubMed, CAS, Scopus and Google Scholar

- Research which is freely available for redistribution 